\title{
ERYTHROCYTE PRESERVATION. VI. THE STORAGE OF BLOOD WITH PURINE NUCLEOSIDES ${ }^{1}$
}

\author{
By DENNIS M. DONOHUE, CLEMENT A. FINCH, AND BEVERLY WESCOTT GABRIO
}

\author{
(From the Department of Medicine, University of Washington School of Medicine, and The \\ King County Central Blood Bank, Seattle, Wash.)
}

(Submitted for publication September 23, 1955; accepted December 19, 1955)

The addition of adenosine to stored blood results in a chemical restoration of deteriorated erythrocytes and sustains their viability during continued storage $(1,2)$. This phenomenon has been referred to as the in vitro reversibility of a biochemical lesion of storage. Apart from the implications of this reaction in red cell metabolism (3), it seemed of importance to evaluate the effect of adenosine in the preservation of blood. The present study indicates that adenosine and some related purine nucleosides retard the onset of the storage lesion and extend significantly the period of viability of stored blood. The effective concentration of these supplements, as well as their potential toxicity, is discussed.

\section{METHODS}

The techniques for the measurements of erythrocyte phosphate partition, blood glucose, sodium and potassium, osmotic fragility, and aerobic utilization of glucose have been described $(1,4)$. Oxygen content and oxygen capacity of erythrocytes were determined by the method of Van Slyke and Neill (5).

Isotonic saline solutions of adenosine and its analogs were employed in concentrations of 50 to $100 \mu$ moles per $\mathrm{ml}$. The nucleosides are soluble in warm saline. While relatively unstable with respect to re-precipitation at these concentrations, the nucleosides can be redissolved by subsequent heating. Sterilization of the solutions was accomplished by filtration through an ultrafine fritted pyrex glass disc. The method for the determination of adenosine concentration and absorption 2 has been reported (1).

In the experiments reported, the control sample refers to blood stored in $\mathrm{ACD}^{3}$ alone. On the basis of in vitro studies on the synthesis of organic phosphate esters

1 This investigation was supported in part by research grants from the United States Atomic Energy Commission (Contract AT(45-1)-343) and the Department of the Army, Office of the Surgeon General (Contracts DA-49-007-MD-508 and DA-007-MD-512).

2 Although this phenomenon could be absorption into the cell and/or adsorption onto the membrane, we shall use the term, absorption, throughout.

8 National Institutes of Health, Formula B. in stored blood, it was found unnecessary to maintain similar volumes in the samples within one experiment, and there were no additions made to the control aliquots, although nucleoside solutions were added to the experimental aliquots.

Post transfusion survival of stored red cells was measured with a double isotope technique in which $\mathrm{Cr}^{\mathrm{s}_{1}}$ was employed as a tag for stored cells, and $\mathrm{P}^{\mathrm{x}}$-labeled fresh cells were used as a blood volume reference (6). When the measurements were performed in duplicate, the accuracy of the survival determination was considered to be \pm 5 per cent. Theoretical survival was determined from the ratio of the two isotopes. Subsequent survival of the $\mathrm{Cr}^{51}$-tagged cells was determined over a period of seven days. An excess loss of $\mathrm{Cr}^{\mathrm{si}}$ of about 10 per cent occurs during the first 24 hours when washed fresh cells are transfused. The reported survival data are thus somewhat lower than would be expected from comparable studies employing the technique of differential agglutination of erythrocytes (Ashby). Before transfusion, cells stored with nucleosides, as well as control cells, were washed three times with saline. Hemolysis incident to washing was not usually significant before the 60 th day of storage.

Toxicity measurements were carried out in rabbits and dogs by the intravenous administration of sterile saline solutions of the purine nucleosides and related products. In addition, plasma, and hemolyzed and fresh red cells from blood stored in ACD plus adenosine, were tested. Rabbits were anesthetized with ether, and dogs were given sodium pentobarbital intravenously. The blood pressure, pulse pressure, and heart rate were recorded directly from the cannulated femoral artery by means of a Sanborn Electromanometer Model No. 120 and a Sanborn Poly-Viso Recorder. A simultaneous electrocardiogram was obtained.

\section{RESULTS}

\section{Adenosine as a supplement to $A C D$ in blood preservation}

A. Rabbit blood. The effects of a single initial supplement of adenosine compared with intermittent addition of this nucleoside during storage are illustrated by the following typical experiment. Blood, collected in ACD, was divided into three parts. Aliquot 1 served as a control. To Aliquot 
TABLE I

Storage of rabbit blood in $A C D+$ adenosine at $4^{\circ} \mathrm{C} .{ }^{*}$

\begin{tabular}{|c|c|c|c|c|}
\hline \multirow{2}{*}{$\begin{array}{c}\text { Days } \\
\text { storage }\end{array}$} & \multicolumn{2}{|c|}{ 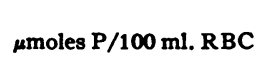 } & \multirow{2}{*}{$\begin{array}{c}\text { Cumulative } \\
\text { absorption } \\
\text { of adenosine } \\
\text { (\%) }\end{array}$} & \multirow{2}{*}{$\begin{array}{c}\text { Survival } \\
\text { of } R B C \\
(\%)\end{array}$} \\
\hline & Inorganic & Organic & & \\
\hline 0 & 142 & 2,442 & & \\
\hline $\begin{array}{r}15 \\
\text { C-1 } \\
\text { A-2 } \\
\text { A-3 }\end{array}$ & $\begin{array}{r}1,130 \\
184 \\
174\end{array}$ & $\begin{array}{l}1,036 \\
2,353 \\
2,443\end{array}$ & $\begin{array}{l}58 \\
62\end{array}$ & $\begin{array}{l}74 \\
95 \\
86\end{array}$ \\
\hline $\begin{array}{r}22 \\
C-1 \\
A-2 \\
A-3\end{array}$ & $\begin{array}{r}1,317 \\
292 \\
180\end{array}$ & $\begin{array}{r}601 \\
2,220 \\
2,454\end{array}$ & $\begin{array}{l}66 \\
66\end{array}$ & $\begin{array}{l}68 \\
87 \\
88\end{array}$ \\
\hline $\begin{array}{r}29 \\
\text { C-1 } \\
\text { A-2 } \\
\text { A-3 }\end{array}$ & $\begin{array}{r}1,400 \\
459 \\
188\end{array}$ & $\begin{array}{r}519 \\
1,997 \\
2,541\end{array}$ & $\begin{array}{l}77 \\
71\end{array}$ & $\begin{array}{l}53 \\
86 \\
86\end{array}$ \\
\hline $\begin{array}{r}36 \\
\text { C-1 } \\
\text { A-2 } \\
\text { A-3 }\end{array}$ & $\begin{array}{r}1,470 \\
615 \\
199\end{array}$ & $\begin{array}{r}362 \\
1,641 \\
2,563\end{array}$ & $\begin{array}{l}81 \\
74\end{array}$ & $\begin{array}{l}38 \\
82 \\
83\end{array}$ \\
\hline $\begin{array}{r}43 \\
\text { C-1 } \\
\text { A-2 } \\
\text { A-3 }\end{array}$ & $\begin{array}{r}1,497 \\
775 \\
151\end{array}$ & $\begin{array}{r}348 \\
1,523 \\
2,278\end{array}$ & $\begin{array}{l}86 \\
77\end{array}$ & $\begin{array}{l}20 \\
66 \\
76\end{array}$ \\
\hline $\begin{array}{r}50 \\
\text { C-1 } \\
\text { A-2 } \\
\text { A-3 }\end{array}$ & $\begin{array}{r}1,500 \\
863 \\
174\end{array}$ & $\begin{array}{r}289 \\
1,153 \\
2,581\end{array}$ & $\begin{array}{l}90 \\
80\end{array}$ & $\begin{array}{r}7 \\
66 \\
81\end{array}$ \\
\hline
\end{tabular}

* Blood was collected in ACD and divided into three aliquots: 1) Control (C-1); 2) Initial addition of 2,800 $\mu$ moles adenosine per $100 \mathrm{ml}$. RBC (A-2); 3) Addition of $1,400 \mu$ moles adenosine per $100 \mathrm{ml}$. RBC weekly (A-3).

2 was added $2800 \mu$ moles adenosine per $100 \mathrm{ml}$. erythrocytes $(\mathrm{RBC})$ at the beginning of storage. To Aliquot 3, $1425 \mu$ moles adenosine per $100 \mathrm{ml}$. $\mathrm{RBC}$ was added initially and the same amount each week throughout the storage period of 50 days. As shown in Table $I$, the per cent absorption ${ }^{2}$ of adenosine was approximately the same in the treated samples, although the absolute amount taken up by the cells at 50 days in Aliquot 3 ( $7300 \mu$ moles per $100 \mathrm{ml}$. RBC) was almost threefold greater than the uptake in Aliquot 2 (2590 $\mu$ moles). Higher levels of cellular organic phosphates were maintained in Aliquot 3, suggesting an increased utilization for this purpose. Erythrocytes of both treated samples retained their organic phosphate components (adenosine triphosphate, hexose phosphate, and 2,3-diphosphoglycerate) considerably better than did the control.

The correlated post-transfusion survival meas- urements (Table I) showed that at 15 days of storage, the erythrocytes stored in ACD alone were 74 per cent viable, while Aliquot 2 had 95 per cent survival, and Aliquot 3, 86 per cent. At this time the amount of adenosine available to the cells in the latter two samples was the same ( 2800 $\mu$ moles). This amount had been available to Aliquot 2 from the beginning of storage, while only $1400 \mu$ moles was present in Aliquot 1 for the first week. The expected decline in survival of the control cells occurred subsequently. Both adenosine-supplemented samples showed about 85 per cent survival through 36 days. Thereafter, the viability of the erythrocytes of Aliquot 3 was better than that of Aliquot 2. Apparently the initial addition of adenosine, at the level employed, was adequate to maintain the red cells throughout the first five weeks of storage, and the weekly additions were not of additional benefit.

In Table II are shown the results of a longterm storage experiment in which rabbit blood was supplemented intermittently with 2300 to $2500 \mu$ moles adenosine per $100 \mathrm{ml}$. RBC. Approximately 70 per cent of the adenosine was absorbed. A sediment, noted in the treated blood sample at 105 days of storage, was presumed to represent precipitated adenosine or its degradation product. This did not appear to affect the phosphate partition or the survival of these cells. The improved maintenance of the energy potential of

TABLE II

Storage of rabbit blood in $A C D+$ adenosine at $4^{\circ} \mathrm{C}$. for 105 days*

\begin{tabular}{|c|c|c|}
\hline $\begin{array}{c}\text { Days } \\
\text { storage }\end{array}$ & $\begin{array}{c}\boldsymbol{\mu} \text { moles Organic } \\
\mathrm{P} / 100 \mathrm{ml} \text {. } \\
\mathrm{RBC}\end{array}$ & $\begin{array}{c}\begin{array}{c}\text { Survival } \\
\text { of RBC } \\
(\%)\end{array} \\
\end{array}$ \\
\hline 0 & 2,504 & \\
\hline $\begin{array}{l}25 \\
\text { Control } \\
\text { Adenosine }\end{array}$ & $\begin{array}{r}847 \\
2,000\end{array}$ & $\begin{array}{l}44 \\
65\end{array}$ \\
\hline $\begin{array}{l}54 \\
\text { Control } \\
\text { Adenosine }\end{array}$ & $\begin{array}{r}408 \\
1,417\end{array}$ & $\begin{array}{r}5 \\
56\end{array}$ \\
\hline${ }^{77}$ Adenosine & 1,431 & 59 \\
\hline 105 Adenosine & 1,271 & 44 \\
\hline
\end{tabular}

* Blood was collected in ACD and divided into two aliquots: 1) Control; 2) Adenosine (2,300 to $2,500 \mu$ moles per $100 \mathrm{ml}$. RBC) added on days $1,25,54$, and 77 . 
TABLE III

Post-transfusion survival of human blood stored in $A C D$ tadenosine at $4^{\circ} \mathrm{C} .^{*}$

\begin{tabular}{cc}
\hline $\begin{array}{c}\text { Days } \\
\text { storage }\end{array}$ & $\begin{array}{c}\text { Survival } \\
\text { of } \mathrm{RBC} \\
(\%)\end{array}$ \\
\hline 19 Control & 77 \\
Adenosine & 91 \\
42 Control & 29 \\
Adenosine & 65 \\
68 Control & \\
Adenosine & 4 \\
\hline
\end{tabular}

* Human blood was collected in ACD and divided into two aliquots: 1) Control; 2) $2,500 \mu$ moles adenosine per $100 \mathrm{ml}$. RBC added at days 1,19 , and 42 .

the cells, as indicated by organic phosphate levels, is evident in the adenosine-treated cells throughout storage. Prolongation of viability was demonstrated in the treated blood as compared with the control cells which were completely non-viable by the 50th day of storage.

B. Human blood. Comparable experiments were performed with human blood. In a typical study, $2500 \mu$ moles adenosine per $100 \mathrm{ml}$. RBC was added every three weeks for approximately 10 weeks. The increased survival time of the adenosine-treated cells over a period of 68 days is shown in Table III. Other data which included phosphate partitions, osmotic fragilities, and determinations of the sodium-potassium gradient also indicated improved chemical characteristics of the erythrocyte when compared with the control blood stored in ACD alone.

C. Miscellaneous studies. Morphologic studies of red cells stored in ACD compared with those stored with the addition of adenosine showed some difference, but this could not be expressed quantitatively. The progressive spherocytosis, poikilocytosis, and crenation of stored blood was somewhat retarded by the addition of adenosine. Likewise, the flickering phenomenon, thought to bear some relation to normal function of the red cell (7), was maintained over a longer period of time. However, it was impossible to predict viability from these changes. The alterations in cell appearance, observed after 60 to 120 days of storage, were still compatible with appreciable cell survival (Tables II, III), which suggests that many of these morphologic changes are reversible upon re-entrance of the erythrocyte into active circulation. Appreciable spontaneous hemolysis was not observed before the 50th day of storage in blood stored in ACD + adenosine. As the storage period approached the 100 th day some hemolysis was clearly visible, although less marked than that in blood stored in ACD alone, and further lysis of cells occurred when the cells were washed before transfusion. Correction for hemolysis was included in the calculation of viability when cells were stored for prolonged periods.

Inasmuch as blood stored in ACD + adenosine is bright red after several weeks of storage, in contrast to the darker color of blood preserved in ACD alone, the oxygen content and capacity ${ }^{4}$ of such blood were measured. The results, recorded in Table IV, suggest a decreased oxygen utilization of red cells during storage in blood supplemented with adenosine. Concomitant analyses of aerobic utilization of glucose also showed the improved metabolic activity of erythrocytes stored several weeks in ACD + adenosine.

TABLE IV

Oxygen content and capacity of human blood during storage *

\begin{tabular}{|c|c|c|c|c|}
\hline $\begin{array}{c}\text { Days } \\
\text { storage }\end{array}$ & $\begin{array}{c}\mathrm{O}_{2} \\
\text { Content } \\
\text { (øol. \%) }\end{array}$ & $\begin{array}{c}\mathrm{O}_{2} \\
\text { Capacity } \\
\text { (ool. \%) }\end{array}$ & $\begin{array}{c}\% \\
\text { Sat. } \\
\text { with O2 }\end{array}$ & $\begin{array}{c}O_{2} \\
\text { uptaket } \\
\text { mlikers/hr.l } \\
\text { ml. } R B C\end{array}$ \\
\hline $\begin{array}{l}1 \text { day: } \\
\text { Control } \\
\text { Adenosine }\end{array}$ & $\begin{array}{l}10.42 \\
12.19\end{array}$ & $\begin{array}{l}14.67 \\
14.58\end{array}$ & $\begin{array}{l}71.0 \\
83.6\end{array}$ & $\begin{array}{l}116 \\
117\end{array}$ \\
\hline $\begin{array}{l}3 \text { weeks: } \\
\text { Control } \\
\text { Adenosine }\end{array}$ & $\begin{array}{l}6.50 \\
8.89\end{array}$ & $\begin{array}{l}13.02 \\
13.40\end{array}$ & $\begin{array}{l}49.9 \\
63.3\end{array}$ & $\begin{array}{r}72 \\
106\end{array}$ \\
\hline $\begin{array}{l}7 \text { weeks: } \\
\text { Control } \\
\text { Adenosine }\end{array}$ & $\begin{array}{l}3.74 \\
6.50\end{array}$ & $\begin{array}{l}12.20 \\
12.37\end{array}$ & $\begin{array}{l}30.7 \\
52.6\end{array}$ & $\begin{array}{r}46 \\
103\end{array}$ \\
\hline
\end{tabular}

* Blood was collected in ACD and divided into two aliquots: 1) Control; 2) $2,500 \mu$ moles adenosine per $100 \mathrm{ml}$. RBC added after 1-day sampling and after 3 weeks' storage. Both aliquots were equilibrated initially with nitrogen, and sampling was accomplished under anaerobic conditions.

$\dagger$ Aerobic utilization of glucose in cell suspension system: Main compartment: $0.01 \mathrm{ml}$. of 1 per cent methylene blue, $0.30 \mathrm{ml}$. of 1.8 per cent glucose, $1.00 \mathrm{ml}$. of red cell suspension, $1.70 \mathrm{ml}$. of $\mathrm{M} / 10$ phosphate buffer, $\mathrm{pH} 7.5$; center well: $0.20 \mathrm{ml}$. of $5 \mathrm{~N} \mathrm{NaOH}$. $\mathrm{O}_{2}$ gas phase: conventional Warburg apparatus; $37^{\circ}$. (Huennekens, F. M., Liu, L., Myers, H., and Gabrio, B. W., Unpublished observations.)

4 We are indebted to Dr. Robert Bruce for these analyses. 
TABLE V

Effect of glucose on the survival of blood stored with adenosine *

\begin{tabular}{|c|c|c|}
\hline $\begin{array}{c}\text { Days } \\
\text { storage }\end{array}$ & $\begin{array}{c}\text { Glucose } \\
\text { mmoles } / 100 \\
\text { ml. blood }\end{array}$ & $\begin{array}{c}\text { Survival } \\
\text { of } \mathrm{RBC} \\
(\%)\end{array}$ \\
\hline $\begin{array}{l}\mathbf{1} \\
\text { Cit. } \\
\text { Cit. +G† } \\
\text { Cit. +At } \\
\text { Cit. +G+A }\end{array}$ & $\begin{array}{r}490 \ddagger \\
1,500 \\
490 \\
1,600\end{array}$ & \\
\hline $\begin{array}{l}{ }^{14} \\
\text { Cit. } \\
\text { Cit. +G } \\
\text { Cit. +A } \\
\text { Cit. +G+A }\end{array}$ & $\begin{array}{r}24 \\
800 \\
12 \\
1,160\end{array}$ & $\begin{array}{l}18 \\
70 \\
36 \\
82\end{array}$ \\
\hline
\end{tabular}

* Human blood was collected in 4 per cent citrate ( 1 vol. +9 vol. blood) and divided into four aliquots: 1) Control citrated blood; 2) Added 1,010 $\mu$ moles glucose per $100 \mathrm{ml}$. blood; 3) Added 1,100 $\mu$ moles adenosine per $100 \mathrm{ml}$. blood; 4) Added 1,010 $\mu$ moles glucose and 1,100 $\mu$ moles adenosine per $100 \mathrm{ml}$. blood. All samples were stored for 2 weeks at $4^{\circ} \mathrm{C}$

$+\mathrm{G}=$ glucose $\mathrm{A}=$ adenosine.

$\$ 490 \mu$ moles glucose per $100 \mathrm{ml}$. blood represents the amount of glucose endogenous in the whole blood in each sample.

\section{Adenosine as a substitute for glucose in blood preservation}

It has been shown (1) that adenosine can reverse the biochemical lesion of stored red cells in the absence of glucose. These results were obtained upon incubation of the aged cells with the riboside at $37^{\circ} \mathrm{C}$. for one hour. In addition, Prankerd and Altman (8) have reported that erythrocytes can utilize adenosine in place of glucose to promote phosphate exchange when incubated over a six-hour period. It was of interest, therefore, to ascertain whether adenosine could replace glucose in maintaining viability of the red cell over a long period of storage at $4^{\circ} \mathrm{C}$. The data shown in Table $\mathrm{V}$ indicate that, with only endogenous levels of glucose present in blood, there was almost complete glucose utilization in the presence of $1100 \mu$ moles of adenosine per 100 $\mathrm{ml}$. whole blood, and the preservation of citrated blood was improved only slightly. At higher levels of glucose supplementation, a sparing action of adenosine on the utilization of glucose and improved viability of red cells could be demonstrated.

Inasmuch as the level of adenosine employed in the previous experiment was about equimolar to glucose, it was thought that a replacement mechanism might require greater amounts of the ri- boside. Consequently, citrated rabbit blood was stored with excess adenosine for four weeks (total of $15,000 \mu$ moles per $100 \mathrm{ml}$. RBC added at intervals). There was an appreciable sparing of glucose utilization in the presence of a large amount of adenosine. The viability of cells stored in citrate + excess adenosine was 59 per cent and that of citrate + glucose was 50 per cent at four weeks of storage. However, the combination of both glucose and adenosine resulted in even better survival (85 per cent).

\section{Effects of related nucleosides}

Nucleosides related to adenosine, such as inosine, deoxyadenosine, guanosine, and xanthosine, similarly stimulated a resynthesis of organic phosphates in the stored erythrocyte after one hour incubation at $37^{\circ} \mathrm{C}$. (3). The implications of this and the mechanism of action of nucleosides will be discussed in a subsequent communication.

Inasmuch as significant reversal of the chemical changes of the storage lesion can be accomplished with purine nucleosides other than adenosine, and since adenosine has been found to have potentially toxic properties, the viability of red cells stored with other nucleosides was determined.

A detailed study of deoxyadenosine, the least effective of the nucleosides on the basis of in vitro studies, is shown in Tables VI and VII. When this substance was added at the beginning of storage only, the optimal level for viability appeared to be $2600 \mu$ moles per $100 \mathrm{ml}$. RBC, regardless of the fact that the level of organic phosphate esters was maintained better in the presence of an excess of the compound. The effect

TABLE VI

Concentration of deoxyadenosine in the storage of human blood*

\begin{tabular}{ccc}
\hline \hline \multirow{2}{*}{$\begin{array}{c}\text { Deoryadenosine } \\
\text { added } \\
\text { (mmoles/100 } \\
\text { ml. } R B C \text { ) }\end{array}$} & \multicolumn{2}{c}{48 days' storage } \\
\cline { 2 - 3 } & $\begin{array}{c}\text { Organic } P \\
\text { (umples/100 } \\
\text { ml. } R B C)\end{array}$ & $\begin{array}{c}\text { Survival } \\
\text { of RBC } \\
(\%)\end{array}$ \\
\hline 0 & 154 & 5 \\
230 & 223 & 8 \\
600 & 240 & 15 \\
1,200 & 418 & 32 \\
2,600 & 660 & 51 \\
5,200 & 925 & 52 \\
\hline
\end{tabular}

* Human blood was collected in ACD, divided into aliquots, supplemented with increasing concentrations of deoxyadenosine, and stored at $4^{\circ} \mathrm{C}$. for 48 days. 
TABLE VII

Storage of human blood in $A C D+$ deoxyadenosine

\begin{tabular}{|c|c|c|c|c|}
\hline & \multicolumn{2}{|c|}{$\begin{array}{l}\mu \text { moles Nucleoside/ } \\
100 \mathrm{ml} \text {. RBC }\end{array}$} & \multirow{2}{*}{$\begin{array}{l}\text { Nucleo- } \\
\text { absorp- } \\
\text { tion } \\
(\%)\end{array}$} & \multirow[b]{2}{*}{$\begin{array}{c}\text { Survival } \\
\text { of } R B C \\
(\%)\end{array}$} \\
\hline & $\begin{array}{c}\text { Added } \\
\text { initially }\end{array}$ & $\begin{array}{c}\text { Other } \\
\text { additions }\end{array}$ & & \\
\hline $\begin{array}{l}\text { Exp. I. } 42 \text { da. storage } \\
\text { Control } \\
\text { D*1 } \\
\text { D2 }\end{array}$ & $\begin{array}{l}3,500 \\
3,500\end{array}$ & 7,000 & $\begin{array}{l}75 \\
69\end{array}$ & $\begin{array}{l}12 \\
69 \\
74\end{array}$ \\
\hline $\begin{array}{l}\text { Exp. II. } 48 \mathrm{da} \text {. storage } \\
\text { Control } \\
\text { A* }^{*} \\
\text { D1 } \\
\text { D2 }\end{array}$ & $\begin{array}{l}2,000 \\
2,000 \\
2,000\end{array}$ & 5,000 & $\begin{array}{l}74 \\
73 \\
62\end{array}$ & $\begin{array}{l}12 \\
45 \\
41 \\
64\end{array}$ \\
\hline
\end{tabular}

* $\mathrm{D}=$ deoxyadenosine; $\mathrm{A}=$ adenosine.

of the deoxyriboside was comparable to that of adenosine in prolonging viability of stored red cells. Similarly, it was most efficacious when added at intervals throughout storage in order to maintain a higher concentration of the nucleoside and a greater absolute absorption.

Blood stored with xanthosine resulted in a sediment formation and was not tested for survival.

\section{Toxicity of nucleosides}

Preliminary studies were undertaken in order to evaluate the relative toxicity for animals of adenosine and its analogs. Of the effects reported, hypotension appeared to be the most important and sensitive for assay purposes (9). A study was conducted on the effects of the intravenous administration of commercially available nucleosides $^{5}$ as well as plasma and washed red cells from blood stored in ACD + adenosine.

The average minimal intravenous dose of adenosine producing a depressor response was $1 \mu$ mole in the rabbit and $10 \mu$ moles in the dog. The average blood pressure fall was $80 \mathrm{~mm}$. $\mathrm{Hg}$ in four to ten seconds after injection. The duration of the effect was variable, increasing with greater doses to as much as 200 seconds when $500 \mu$ moles was given intravenously to a dog. There were no significant electrocardiographic changes in rabbits given 10 times the minimal hypotensive dose. The administration of amounts up to 100 times the minimal dose did not produce fatalities. The results were comparable in the two species.

o Obtained from Schwarz Laboratories, Mt. Vernon, New York.
Solutions of guanosine, xanthosine, and inosine did not cause an observable effect in amounts up to ten times the minimal hypotensive dosage of adenosine. A significant fall in blood pressure was observed in the dog after $400 \mu$ moles of deoxyadenosine was given. Thus the relative hypotensive effect of deoxyadenosine was estimated to be less than 5 per cent that of adenosine. Adenosine-5-phosphate was equal to adenosine in toxicity but ribose and adenine were without effect. It was demonstrated further that injected plasma from blood stored 14 days in ACD plus adenosine produced transient and mild hypotension, while injection of washed intact erythrocytes was without effect.

\section{DISCUSSION}

The incubation of stored blood with adenosine and other nucleosides results in a repletion of cellular organic phosphates and an increased ability of the cells to utilize glucose aerobically (1). This restoration of the energy potential has been associated, as well, with improvement in osmotic fragility, an increase in intracellular potassium and improvement in post-transfusion viability (2). From the data in the present communication, it is evident that the addition of adenosine (2500 $\mu$ moles per $100 \mathrm{ml} . \mathrm{RBC}$ ) as a supplement to $\mathrm{ACD}$ during the storage of blood at $4^{\circ} \mathrm{C}$. prolongs the period of useful storage to about 40 to 50 days. Supplementation at weekly intervals was shown to improve viability over an additional period of time.

The use of citrate alone as a preservative is associated with a rapid loss of cell viability, while the addition of glucose prolongs the useful storage period from 5 to 15 days, and an acid-citratedextrose medium extends this period to 21 days. Although adenosine added to citrated blood also improves viability, supplementation with both adenosine and glucose provides the best results. This implies that adenosine and glucose are complementary and neither completely substitutes for the other.

The hypotension produced in rabbits and dogs with small amounts of adenosine ( 1 to $10 \mu$ moles) indicates the potentially hazardous effects of this substance. Only a small amount of adenosine- 
treated blood has been transfused and only after repeated washing of the cells. Related purine nucleosides were found to be less "toxic," but only deoxyadenosine was studied in some detail.

It has been suggested $(1,3)$ that nucleosides provide the necessary substrate through phosphorolytic cleavage, and that the resultant ribose-1phosphate participates through the aerobic shunt pathway in the energy-yielding reactions to maintain the cell. The existence of a nucleoside phosphorylase in this reaction is implicit in the work of Dische (10) and has been isolated in purified form from human erythrocytes (3). Inasmuch as inosine and guanosine are split readily by this phosphorylase and adenosine only at a very slow rate, it would appear that the action of adenosine could be explained by an initial conversion to inosine and subsequent cleavage to ribose-1-phosphate and hypoxanthine (3). This conversion can occur by means of an adenosine deaminase which has been found in the erythrocyte $(11,12)$. Thus this reaction sequence would implicate inosine as the actual effective agent in erythrocyte preservation, and further studies with this nucleoside will be reported subsequently.

\section{SUMMARY}

The addition of adenosine to rabbit or human blood stored at $4^{\circ} \mathrm{C}$. in acid-citrate-dextrose improves the preservation of erythrocytes. The chemical characteristics of the red cell are improved, and the effective period of storage is approximately twice as long as with acid-citrate-dextrose alone. In high concentrations adenosine without glucose extends the period of viability of citrated blood and reduces the glucose consumption. However, both adenosine and glucose are necessary to provide optimal cell preservation. A similar effect is produced by related purine nucleosides, such as deoxyadenosine. The relative toxicity of these compounds when administered intravenously, and a possible mechanism of action of adenosine in blood preservation are discussed.

\section{ACKNOWLEDGMENT}

The authors wish to thank Miss Marion Hennessey, Mrs. Joan Thomasson, and Mrs. Eloise Hardin, for expert technical assistance.

\section{REFERENCES}

1. Gabrio, B. W., Hennessey, M., Thomasson, J., and Finch, C. A., Erythrocyte preservation. IV. In vitro reversibility of the storage lesion. J. Biol. Chem., 1955, 215, 357.

2. Gabrio, B. W., Donohue, D. M., and Finch, C. A., Erythrocyte preservation. V. Relationship between chemical changes and viability of stored blood treated with adenosine. J. Clin. Invest., 1955, 34, 1509.

3. Gabrio, B. W., and Huennekens, F. M., Nucleoside metabolism of stored erythrocyte. Federation Proc., 1955, 14, 217.

4. Gabrio, B. W., and Finch, C. A., Erythrocyte preservation. I. The relation of the storage lesion to in vivo erythrocyte senescence. J. Clin. Invest., 1954, 33, 242.

5. Van Slyke, D. D., and Neill, J. M., The determination of gases in blood and other solutions by vacuum extraction and manometric measurements. I. VII. Determination of oxygen in blood. J. Biol. Chem., 1924, 61, 554.

6. Donohue, D. M., Motulsky, A. G., Giblett, E. R., Pirzio-Biroli, G., Viranuvatti, V., and Finch, C. A., The use of chromium as a red-cell tag. Brit. J. Hematol., 1955, 1, 249.

7. Blowers, R., Clarkson, E. M., and Maizels, M., Flicker phenomenon in human erythrocytes. $J$. Physiol., 1951, 113, 228.

8. Prankerd, T. A. J., and Altman, K. I., The effect of adenosine on the phosphate exchange in mammalian red blood cells. Biochim. et Biophys. Acta, 1954, 15, 158.

9. Green, H. N., and Stoner, H. B., Biological Actions of the Adenine Nucleotides. London, Lewis, 1950.

10. Dische, Z., Synthesis of hexosemono- and diphosphate from adenosine and ribose-5-phosphate in human blood in Symposium on Phosphorus Metabolism, Johns Hopkins University, 1951, vol. I, p. 171.

11. Drury, A. N., Lutwak-Mann, C., and Solandt, O. M., The inactivation of adenosine by blood, with special reference to cat's blood. Quart. J. Exper. Physiol., 1938, 27, 215.

12. Schaedel, M. L., and Schlenk, F., Adenosine and adenosine deaminase. Texas Rep. Biol. \& Med., 1948, 6, 176. 